\title{
KOMPETENSI PEDAGOGIK GURU PAUD DALAM MENGEMBANGKAN PEMBELAJARAN UNTUK ANAK USIA DINI
}

\author{
Margaretha Sri Yuliariatiningsih
}

Taty Setiaty

\begin{abstract}
Abstrak
Undang-Undang Nomor 14 tahun 2005 tentang guru dan dosen yang menyatakan bahwa guru dan dosen adalah jabatan profesional. Jabatan profesional adalah jabatan yang memerlukan kemampuan tertentu dan latar belakang pendidikan tertentu. Selanjutnya menurut PP Menteri Pendidikan Nasional RI No 16 Tahun 2007 tentang standar kualifikasi akademik dan kompetensi guru dikatakan bahwa kompetensi yang diperlukan oleh guru terbagi atas empat kategori, yaitu: Kompetensi Pedagogi (Akademik), Kompetensi Kepribadian, Kompetensi sosial (kemasyarakatan), dan Kompetensi profesional. Pendidikan usia dini merupakan usaha mengupayakan dan mengembangkan seluruh potensi kemampuan anak sejak lahir sampai berusia 6 tahun yang pada akhirnya merupakan fondasi awal untuk mengembangkan bangsa, maka dari itu dibutuhkan tenaga pendidik yang mampu mengembangkan seluruh potensi anak usia dini tersebut. Karena perannya yang sangat penting, guru PAUD dituntut memiliki profesionalisme yang tinggi dalam melaksanakan tugasnya dan kesediaannya untuk berubah ke arah yang lebih baik.
\end{abstract}

\section{Kata Kunci: Kompetensi Pedagogi, Guru PAUD, Pembelajaran, Anak Usia Dini}

\section{A. Pendahuluan}

PAUD Merupakan komitmen dunia dan pemerintah Indonesia telah menyatakan komitmennya terhadap deklarasi dunia yang menyangkut PAUD. Komitmen dunia tersebut, di antaranya:

1. Komitmen Jomtien Thailand (1990): Pendidikan untuk semua orang, sejak lahir sampai menjelang ajal.

2. Deklarasi Dakkar (2000): Memperluas dan memperbaiki keseluruhan perawatan dan pendidikan anak usia dini secara komprehensif terutama yang sangat rawan dan terlantar.

Dasar hukum PAUD di Indonesia adalah sebagai berikut.

1. Pembukaan UUD 1945 ; Salah satu tujuan kemerdekaan adalah mencerdaskan kehidupan bangsa.

2. Amandemen UUD 1945 pasal 28 C : Setiap anak berhak mengembangkan diri melalui pemenuhan kebutuhan dasarnya, berhak mendapat pendidikan dan memperoleh manfaat dari ilmu pengetahuan dan teknologi, seni dan budaya demi meningkatkan kualitas hidupnya dan demi kesejahteraan umat manusia.'

3. UU No. 23/2002 Tentang Perlindungan Anak Pasal 9 ayat (1) 'Setiap anak berhak memperoleh pendidikan dan pengajaran dalam rangka pengembangan pribadinya dan tingkat kecerdasannya sesuai dengan minat dan bakat.'

4. UU No 20/2003 pasal 28 (tentang PAUD) 
Perhatian hukum tersebut berkembang seiring dipahaminya peran penting masa emas pada rentang usia dini, bahwa:

1. Perkembangan anak usia dini lebih kritis dibandingkan dengan perkembangan berikutnya. Hal ini disebabkan perkembangan anak berlangsung secara berkesinambungan, artinya perkembangan suatu tahap akan berpengaruh terhadap perkembangan tahap berikutnya, dan pola kepribadian anak berkembang menjadi relatif tetap (Slavin, 1994: 73). Karena saat tersebut merupakan masa yang sangat penting, maka pendidikan TK menjadi sangat penting bagi perkembangan anak selanjutnya

2. PAUD sebagai titik sentral strategi pembangunan sumber daya manusia dan sangat fundamental terhadap keberlangsungan pembangunan masyarakat Indonesia

3. PAUD memegang peranan penting dan menentukan bagi sejarah perkembangan anak selanjutnya, sebab merupakan fondasi dasar bagi kepribadian anak.

4. Anak yang mendapatkan pembinaan sejak dini akan dapat meningkatkan kesehatan dan kesejahteraan fisik maupun mental yang akan berdampak pada peningkatan prestasi belajar, etos kerja, produktivitas, pada akhirnya anak akan mampu lebih mandiri dan mengoptimalkan potensi yang dimilikinya.

5. Merupakan Masa Golden Age (Usia Keemasan) karena tahap perkembangan otak pada anak usia dini menempati posisi yang paling vital yakni mencapai 80\% perkembangan otak.

6. Cerminan diri untuk melihat keberhasilan anak di masa mendatang karena anak yang mendapatkan layanan baik semenjak usia 0-6 tahun memiliki harapan lebih besar untuk meraih keberhasilan di masa mendatang. Sebaliknya anak yang tidak mendapatkan pelayanan pendidikan yang memadai membutuhkan perjuangan yang cukup berat untuk mengembangkan hidup selanjutnya.

Syamsuddin (2012) menyebutkan kontribusi dampak layanan PAUD adalah: mempersiapkan anak memasuki pendidikan lebih lanjut, mengurangi angka mengulang kelas, mengurangi angka putus sekolah, mempercepat pencapaian wajib belajar, meningkatkan mutu pendidikan, mengurangi angka buta huruf muda, memperbaiki derajat kesehatan gizi anak balita.

Di lain pihak, berdasarkan data tahun 2001 mengungkapkan bahwa dari sekitar 26,2 juta anak usia 0-6 tahun baru sekitar 7,3 juta anak (28 persen), yang telah memperoleh layanan perawatan (care) dan pendidikan anak usia dini (PAUD) melalui berbagai program. Dengan demikian masih ada sekitar 18,8 juta anak yang belum memperoleh layanan PAUD. Sedangkan khusus untuk kelompok anak usia 4-6 tahun, masih terdapat sekitar 10,2 juta (83,8 persen) anak yang belum terlayani oleh program pendidikan prasekolah. Di samping itu walaupun 60 persen anak usia 0-6 tahun tinggal di pedesaan, ternyata prasarana dan sarana PAUD umumnya lebih banyak di perkotaan daripada di pedesaan (Susenas, 2000). 


\section{B. Permasalahan Profesionalisme Guru PAUD di Lapangan}

Permasalahan yang dihadapi dalam meningkatkan kemampuan profesional para guru melaksanakan pembelajaran adalah:

1. Kualifikasi pendidik AUD belum memadai (S1/D4 baru 15,72\%). Guru TK sebagai guru yang menjadi peletak karakter bangsa, rata rata hanya dilakukan oleh ibu-ibu rumah tangga yang tidak memiliki kualifikasi pendidik. Secara nasional komposisi guru menunjukkan bahwa guru Taman Kanak-kanak (TK) termasuk Raudathul Atfal (RA yang sederajat dengan TK) yang masih jenjang atau lulusan SLTA jumlahnya sebanyak 110.000 orang dari jumlah 174.000 guru TK, jadi lulusan S1-nya baru 18.000 orang, kemudian yang lulusan D3 hanya 3000 orang, lulusan D2 berjumlah 32.000 orang, dan lulusan D1 sebanyak 9000 orang. Sedangkan pendidikan profesi harus tuntas dalam waktu 10 tahun setelah undang-undang dilaksanakan. Undang-undang ini dikeluarkan tahun 2005. Jadi pada tahun 2015 harus sudah tersertifikasi dan harus lulus S1 terlebih dahulu.

2. Rekrutmen Guru TK banyak yang asal bersedia mengajar bukan berlatar belakang pendidikan anak usia dini dengan pertimbangan bahwa guru TK hanya sekedar mengajak bermain menyebabkan proses belajar mengajar menjadi salah kaprah.

3. Ketika guru mengajar, tidak ada kontrol dan pengawasan terhadap yang dilakukan dengan pekerjaan tersebut. Apabila guru TK membuat kekeliruan dalam mengajar, tidak ada sanksi apa pun.

4. Sertifikasi menimbulkan kecemburuan dan persaingan tidak sehat manakala terjadi pengajuan sertifikasi guru tersebut didasarkan pada nepotisme

5. Implementasi penataran dan lokakarya sebagai upaya peningkatan kualitas guru sering terpisah dari tugas-tugas keseharian sebagai guru yang mengajar di dalam kelas. Bahkan tidak jarang, yang direkomendasikan dalam penataran atau lokakarya tersebut tidak dapat diaplikasikan di sekolah karena faktor-faktor tertentu, seperti pemahaman kepala sekolah yang kurang memadai akan hakikat bidang kajian yang ditatarkan itu. Oleh karena itu, tidak mengherankan apabila tidak terdapat perubahan kompetensi mengajar yang signifikan antara masa sebelum dan sesudah penataran atau lokakarya.

6. Pelaksanaan otonomi juga membawa persoalan bagi pemerataan jumlah dan kualitas guru, karena saat pihak provinsi tidak mempunyai otoritas untuk mendistribusikan guru ke daerah-daerah sesuai dengan kebutuhan lapangan. Guru-guru yang berkualitas cenderung terkonsentrasi di daerah perkotaan tetapi juga tidak menjamin dalam segi kualitas proses pembelajaran.

7. Sikap Konservatif Guru: Suatu perubahan dalam menerapkan ide atau konsep menuntut adanya perubahan dalam pola kerja pelaksanaan tugas kependidikan. Agar pola kerja itu sesuai, maka perlu pula dimiliki berbagai kemampuan yang ditunjang oleh wawasan dan pengetahuan baru yang sesuai dengan perkembangan ilmu pengetahuan dan teknologi tentang hal itu. Tetapi keterampilan itu tidak dimiliki oleh guru konservatif.

8. Rendahnya motivasi guru untuk meningkatkan kompetensinya atau kurangnya kesadaran akan pentingnya mengikuti perkembangan Ilmu Pengetahuan dan Teknologi Informasi Pendidikan 
9. Terbelenggunya Guru. Guru tidak memiliki kemerdekaan dalam menjalankan profesinya sehingga bertentangan dengan hati nuraninya, karena harus tunduk terhadap kehendak pemberi petunjuk atau kelompok lain. Sebagai contoh guru PAUD harus memberikan calistung secara formal demi untuk memenuhi arahan pihak penyelenggara agar dapat bersaing dengan TK lainnya serta untuk memenuhi tuntutan masyarakat. Guru juga sering diperebutkan untuk kepentingan politis atasan sehingga lebih baik manut dari pada mendapat penilaian buruk bahkan teror terhadap guru yang tidak loyal. Posisi rendah baik secara ekonomi, struktural dan budaya bahwa guru tidak boleh memberi contoh "membangkang", membuat guru tidak berdaya secara politik.

10. Adanya perguruan tinggi swasta sebagai pencetak guru yang lulusannya asal jadi tanpa memperhitungkan outputnya kelak di lapangan sehingga menyebabkan banyak guru yang tidak kompeten.

11. Pengakuan terhadap ilmu pendidikan dan keguruan masih setengah hati dari pengambilan kebijakan dan pihak-pihak terlibat. Hal ini terbukti dari masih belum mantapnya kelembagaan pencetak tenaga keguruan dan kependidikan, rendahnya pemberian kesejahteraan kepada guru serta kurangnya keberpihakan dan kesungguhan para penentu kebijakan.

12. Kompetensi Guru TK masih rendah, terbukti dengan :

a. Guru enggan dan atau kurang memahami bagaimana membuat Program Tahunan (Prota), Program Semester (Promes), bahkan sampai Satuan Kegiatan Harian (SKH). Guru lebih senang mencontek perangkat pembelajaran yang sudah ada tanpa mencermati lebih dalam kekurangan dan kelebihan perangkat tersebut. dan juga maraknya penjualan RPP, LKS dan lembar evaluasi yang dijual melalui internet.

b. Dalam bidang teknologi guru juga belum banyak yang memanfaatkan teknologi informasi dan komunikasi untuk pembelajaran. Banyak guru yang masih gaptek (gagap teknologi) sehingga tidak pernah memanfaatkan internet untuk memperoleh berbagai informasi yang dibutuhkan.

c. Guru kurang mampu membangun suasana belajar yang kondusif untuk belajar mandiri (self-directed learning) dan kegiatan eksplorasi diri,

d. Kenyataan di lapangan, menunjukkan bahwa di mata guru, uji sertifikasi adalah sebuah " revolusi” untuk peningkatan gaji guru. Padahal, ini adalah suatu political will pemerintah dalam rangka meningkatkan kualitas guru yang sangat besar kontribusinya bagi peningkatan mutu pendidikan di Indonesia. Miskonsepsi semacam ini, membuat para guru dapat menghalalkan segala cara dalam membuat portofolionya dengan memalsukan dokumen prestasi atau kinerjanya.

e. Masih banyak guru yang tidak menekuni profesinya secara utuh. Hal ini disebabkan oleh banyak guru yang bekerja di luar jam kerjanya untuk memenuhi kebutuhan hidup sehari-hari sehingga waktu untuk membaca dan menulis untuk meningkatkan diri tidak ada, khususnya terjadi pada guru "nyasar" atau guru "bayar" 


\section{Kebijakan Pemerintah tentang Kompetensi Guru PAUD}

Para ahli mengatakan bahwa abad 21 merupakan abad pengetahuan karena pengetahuan menjadi landasan utama segala aspek kehidupan (Trilling dan Hood, 1999). Abad pengetahuan merupakan suatu era dengan tuntutan yang lebih rumit dan menantang. Perubahan-perubahan yang terjadi selain karena perkembangan teknologi yang sangat pesat, juga diakibatkan oleh perkembangan yang luar biasa dalam ilmu pengetahuan, psikologi, dan transformasi nilai-nilai budaya. Dampaknya adalah perubahan cara pandang manusia terhadap manusia, cara pandang terhadap pendidikan, perubahan peran orang tua/guru/dosen, serta perubahan pola hubungan antar mereka.

Tenaga guru menjadi sangat penting dalam mengantarkan generasi muda untuk menjadi sumber daya manusia (SDM) yang berkualitas dan kompetitif sehingga mampu mewujudkan suatu kesejahteraan bersama. Sejarah peradaban dan kemajuan bangsa-bangsa di dunia membelajarkan pada kita bahwa bukan sumber daya alam (SDA) melimpah yang dominan mengantarkan bangsa tersebut menuju pada kemakmuran, tetapi ketangguhan daya saing dan keunggulan ilmu pengetahuan dan penguasaan teknologi (iptek) bangsa tersebutlah yang berperanan untuk meraup kesejahteraan. Bahkan SDM yang menguasai iptek cenderung memanfaatkan teknologinya untuk menguasai SDA bangsa lain. Pada gilirannya semua itu akan memengaruhi pola-pola pendidikan yang lebih disukai dengan tuntutan kecenderungan tersebut. Dalam hubungan dengan ini pendidikan ditantang untuk mampu menyiapkan sumber daya manusia yang mampu menghadapi tantangan kecenderungan itu tanpa kehilangan nilai-nilai kepribadian dan budaya bangsanya.

Di dalam Undang-Undang Nomor. 20 tahun 2003 tentang Sistem Pendidikan Nasional dikatakan tujuan pendidikan nasional adalah mengembangkan kecerdasan intelektual, emosional, dan spiritual, mengembangkan kesehatan dan akhlak mulia dari peserta didik. Selanjutnya membentuk peserta didik yang terampil, kreatif, dan mandiri. Tujuan ini merupakan tantangan bagi para pendidik (guru), karena tujuan itu merupakan modal dasar bagi peserta didik dalam mengarungi kehidupan abad sekarang dan masa datang. Guru harus mampu mengantarkan peserta didik sesuai tujuan pendidikan nasional dan bersaing dengan kemajuan jaman tersebut. Walaupun guru dan pengajar bukan satu-satunya faktor penentu keberhasilan pendidikan tetapi, pengajaran merupakan titik sentral pendidikan dan kualifikasi, sebagai cermin kualitas tenaga pengajar yang memberikan andil sangat besar bagi kualitas pendidikan yang menjadi tanggung jawabnya.

Undang-Undang Nomor 14 tahun 2005 tentang guru dan dosen yang menyatakan bahwa guru dan dosen adalah jabatan profesional. Jabatan profesional adalah jabatan yang memerlukan kemampuan tertentu dan latar belakang pendidikan tertentu. Dalam Pasal 7 ayat (1) selanjutnya dinyatakan bahwa profesi guru dan profesi dosen merupakan bidang pekerjaan khusus yang dilaksanakan berdasarkan prinsip yakni:

1. memiliki bakat, minat, panggilan jiwa, dan idealisme;

2. memiliki komitmen untuk meningkatkan mutu pendidikan, keimanan, ketakwaan, dan akhlak mulia; 
3. memiliki kualifikasi akademik dan latar belakang pendidikan sesuai dengan bidang tugas;

4. memiliki kompetensi yang diperlukan sesuai dengan bidang tugas;

5. memiliki tanggung jawab atas pelaksanaan tugas keprofesionalan;

6. memperoleh penghasilan yang ditentukan sesuai dengan prestasi kerja;

7. memiliki kesempatan untuk mengembangkan keprofesionalan secara berkelanjutan dengan belajar sepanjang hayat;

8. memiliki jaminan perlindungan hukum dalam melaksanakan tugas keprofesionalan; dan

9. memiliki organisasi profesi yang mempunyai kewenangan mengatur hal-hal yang berkaitan dengan tugas keprofesionalan guru.

Menurut Peraturan Pemerintah RI No.19 Tahun 2005 Tentang Standar Nasional Pendidikan, pasal 29 dikatakan bahwa Pendidik pada pendidikan anak usia dini memiliki: a. kualifikasi akademik minimum diploma empat (D-IV) atau sarjana (S1). b. Latar belakang pendidikan tinggi di bidang pendidikan anak usia dini, kependidikan lain, atau psikologi

Selanjutnya menurut PP Menteri Pendidikan Nasional RI No 16 Tahun 2007 tentang standar kualifikasi akademik dan kompetensi guru dikatakan bahwa kompetensi yang diperlukan oleh guru terbagi atas empat kategori, yaitu: Kompetensi Pedagogi (Akademik), Kompetensi Kepribadian, Kompetensi sosial (kemasyarakatan), dan Kompetensi profesional. Penjabarannya di bawah ini.

\begin{tabular}{|c|c|c|c|}
\hline No. & KOMPETENSI INTI GURU & & KOMPETENSI GURU TK/PAUD \\
\hline \multicolumn{4}{|c|}{ Kompetensi Pedagogi } \\
\hline 1. & $\begin{array}{l}\text { Menguasai karakteristik peserta } \\
\text { didik dari aspek fisik, moral, } \\
\text { sosial, kultural, emosional, dan } \\
\text { intelektual. }\end{array}$ & $\begin{array}{l}1.2 \\
1.3 \\
1.4\end{array}$ & $\begin{array}{l}\text { Memahami karakteristik peserta didik usia } \\
\text { TK/PAUD yang berkaitan dengan aspek fisik, } \\
\text { intelektual, sosial-emosional, moral, dan latar } \\
\text { belakang sosial-budaya. } \\
\text { Mengidentifikasi potensi peserta didik usia } \\
\text { TK/PAUD dalam berbagai bidang } \\
\text { pengembangan. } \\
\text { Mengidentifikasi kemampuan awal peserta didik } \\
\text { usia TK/PAUD dalam berbagai bidang } \\
\text { pengembangan. } \\
\text { Mengidentifikasi kesulitan peserta didik usia } \\
\text { TK/PAUD dalam berbagai bidang } \\
\text { Pengembangan. }\end{array}$ \\
\hline 2. & $\begin{array}{l}\text { Menguasai teori belajar dan } \\
\text { prinsip-prinsip pembelajaran yang } \\
\text { mendidik. }\end{array}$ & $\begin{array}{l}2.1 \\
2.2\end{array}$ & $\begin{array}{l}\text { Memahami berbagai teori belajar dan prinsip- } \\
\text { prinsip bermain sambil belajar yang mendidik } \\
\text { yang terkait dengan berbagai bidang } \\
\text { pengembangan di TK/PAUD. } \\
\text { Menerapkan berbagai pendekatan, strategi, } \\
\text { metode, dan teknik bermain sambil belajar yang } \\
\text { bersifat holistik, otentik, dan bermakna, yang } \\
\text { terkait dengan berbagai bidang pengembangan } \\
\text { di TK/PAUD. }\end{array}$ \\
\hline
\end{tabular}




\begin{tabular}{|c|c|c|c|}
\hline 3. & $\begin{array}{l}\text { Mengembangkan kurikulum yang } \\
\text { terkait dengan bidang } \\
\text { pengembangan yang diampu. }\end{array}$ & 3.4 & $\begin{array}{l}\text { Memahami prinsip-prinsip pengembangan } \\
\text { kurikulum. } \\
\text { Menentukan tujuan kegiatan pengembangan } \\
\text { yang mendidik. } \\
\text { Menentukan kegiatan bermain sambil belajar } \\
\text { yang sesuai untuk mencapai tujuan } \\
\text { pengembangan. } \\
\text { Memilih materi kegiatan pengembangan yang } \\
\text { mendidik yaitu kegiatan bermain sambil belajar } \\
\text { sesuai dengan tujuan pengembangan } \\
\text { Menyusun perencanaan semester, mingguan } \\
\text { dan harian dalam berbagai kegiatan } \\
\text { pengembangan di TK/PAUD. } \\
\text { Mengembangkan indikator dan instrumen } \\
\text { penilaian. }\end{array}$ \\
\hline 4. & $\begin{array}{l}\text { Menyelenggarakan kegiatan } \\
\text { pengembangan yang mendidik }\end{array}$ & $\begin{array}{l}4.4 \\
4.5 \\
4.6\end{array}$ & $\begin{array}{l}\text { Memahami prinsip-prinsip perancangan kegiatan } \\
\text { pengembangan yang mendidik dan } \\
\text { menyenangkan. } \\
\text { Mengembangkan komponen-komponen } \\
\text { rancangan kegiatan pengembangan yang } \\
\text { mendidik dan menyenangkan. } \\
\text { Menyusun rancangan kegiatan pengembangan } \\
\text { yang mendidik yang lengkap, baik untuk } \\
\text { kegiatan di dalam kelas, maupun di luar kelas. } \\
\text { Menerapkan kegiatan bermain yang bersifat } \\
\text { holistik, otentik, dan bermakna. } \\
\text { Menciptakan suasana bermain yang } \\
\text { menyenangkan, inklusif, dan demokratis } \\
\text { Memanfaatkan media dan sumber belajar yang } \\
\text { sesuai dengan pendekatan bermain sambil } \\
\text { belajar. } \\
\text { Menerapkan tahapan bermain anak dalam } \\
\text { kegiatan pengembangan di TK/PAUD. } \\
\text { Mengambil keputusan transaksional dalam } \\
\text { kegiatan pengembangan di TK/PAUD sesuai } \\
\text { dengan situasi yang berkembang. }\end{array}$ \\
\hline 5. & $\begin{array}{l}\text { Memanfaatkan } r \text { teknologi } \\
\text { informasi dan komunikasi untuk } \\
\text { kepentingan penyelenggaraan } \\
\text { kegiatan pengembangan yang } \\
\text { mendidik. }\end{array}$ & 5.1 & $\begin{array}{l}\text { Memanfaatkan teknologi informasi dan } \\
\text { komunikasi untuk meningkatkan kualitas } \\
\text { kegiatan pengembangan yang mendidik. }\end{array}$ \\
\hline 6. & $\begin{array}{l}\text { Memfasilitasi pengembangan } \\
\text { potensi peserta didik untuk } \\
\text { mengaktualisasikan berbagai } \\
\text { potensi yang dimiliki. }\end{array}$ & 6.1 & $\begin{array}{l}\text { Menyediakan berbagai kegiatan bermain sambil } \\
\text { belajar untuk mendorong peserta didik } \\
\text { mengembangkan potensinya secara optimal } \\
\text { termasuk kreativitasnya. }\end{array}$ \\
\hline 7. & $\begin{array}{l}\text { Berkomunikasi secara efektif, } \\
\text { empatik, dan santun dengan } \\
\text { peserta didik. }\end{array}$ & 7.2 & $\begin{array}{l}\text { Memahami berbagai strategi berkomunikasi } \\
\text { yang efektif, empati dan santun, baik secara } \\
\text { lisan maupun tulisan. } \\
\text { Berkomunikasi secara efektif, empati, dan } \\
\text { santun dengan peserta didik dengan bahasa yang }\end{array}$ \\
\hline
\end{tabular}




\begin{tabular}{|c|c|c|c|}
\hline & & & $\begin{array}{l}\text { khas dalam interaksi pembelajaran yang } \\
\text { terbangun secara siklikal dari (a) penyiapan } \\
\text { kondisi psikologis peserta didik, (b) memberikan } \\
\text { pertanyaan atau tugas sebagai undangan kepada } \\
\text { peserta didik untuk merespons, (c) respons } \\
\text { peserta didik, (d) reaksi guru terhadap respons } \\
\text { peserta didik, dan seterusnya. }\end{array}$ \\
\hline \multirow[t]{2}{*}{8.} & $\begin{array}{l}\text { Menyelenggarakan penilaian dan } \\
\text { evaluasi proses dan hasil belajar }\end{array}$ & 8.1 & $\begin{array}{l}\text { Memahami prinsip-prinsip penilaian dan } \\
\text { evaluasi proses dan hasil belajar sesuai dengan } \\
\text { karakteristik lima mata pelajaran SD/MI. }\end{array}$ \\
\hline & & $\begin{array}{l}8.3 \\
8.4 \\
8.5 \\
8.6 \\
8.7\end{array}$ & $\begin{array}{l}\text { Menentukan aspek-aspek proses dan hasil } \\
\text { belajar yang penting untuk dinilai dan dievaluasi } \\
\text { sesuai dengan karakteristik lima mata pelajaran } \\
\text { SD/MI. } \\
\text { Menentukan prosedur penilaian dan evaluasi } \\
\text { proses dan hasil belajar. } \\
\text { Mengembangkan instrumen penilaian dan } \\
\text { evaluasi proses dan hasil belajar. } \\
\text { Mengadministrasikan penilaian proses dan hasil } \\
\text { belajar secara berkesinambungan dengan } \\
\text { menggunakan berbagai instrumen. } \\
\text { Menganalisis hasil penilaian proses dan hasil } \\
\text { belajar untuk berbagai tujuan. } \\
\text { Melakukan evaluasi proses dan hasil belajar. }\end{array}$ \\
\hline 9. & $\begin{array}{l}\text { Memanfaatkan hasil penilaian dan } \\
\text { evaluasi untuk kepentingan } \\
\text { pembelajaran. }\end{array}$ & $\begin{array}{l}9.1 \\
9.2 \\
9.3 \\
9.4\end{array}$ & $\begin{array}{l}\text { Menggunakan informasi hasil penilaian dan } \\
\text { evaluasi untuk menentukan ketuntasan belajar. } \\
\text { Menggunakan informasi hasil penilaian dan } \\
\text { evaluasi untuk merancang program remedial dan } \\
\text { pengayaan. } \\
\text { Mengomunikasikan hasil penilaian dan evaluasi } \\
\text { kepada pemangku kepentingan. } \\
\text { Memanfaatkan informasi hasil penilaian dan } \\
\text { evaluasi pembelajaran untuk meningkatkan } \\
\text { kualitas pembelajaran. }\end{array}$ \\
\hline 10. & $\begin{array}{l}\text { Melakukan tindakan reflektif } \\
\text { untuk peningkatan kualitas } \\
\text { pembelajaran. }\end{array}$ & $\begin{array}{l}10.1 \\
10.2 \\
10.3\end{array}$ & $\begin{array}{l}\text { Melakukan refleksi terhadap pembelajaran yang } \\
\text { telah dilaksanakan. } \\
\text { Memanfaatkan hasil refleksi untuk perbaikan } \\
\text { dan pengembangan lima mata pelajaran SD/MI. } \\
\text { Melakukan penelitian tindakan kelas untuk } \\
\text { meningkatkan kualitas pembelajaran lima mata } \\
\text { pelajaran SD/MI. }\end{array}$ \\
\hline \multicolumn{4}{|c|}{ Kompetensi Kepribadian } \\
\hline 11. & $\begin{array}{l}\text { Bertindak sesuai dengan norma } \\
\text { agama, hukum, sosial, dan } \\
\text { kebudayaan nasional Indonesia. }\end{array}$ & 11.1 & $\begin{array}{l}\text { Menghargai peserta didik tanpa membedakan } \\
\text { keyakinan yang dianut, suku, adat-istiadat, } \\
\text { daerah asal, dan gender. } \\
\text { Bersikap sesuai dengan norma agama yang } \\
\text { dianut, hukum dan norma sosial yang berlaku } \\
\text { dalam masyarakat, serta kebudayaan nasional } \\
\text { Indonesia yang beragam. }\end{array}$ \\
\hline
\end{tabular}




\begin{tabular}{|c|c|c|c|}
\hline 12. & $\begin{array}{l}\text { Menampilkan diri sebagai pribadi } \\
\text { yang jujur, berakhlak mulia, dan } \\
\text { teladan bagi peserta didik dan } \\
\text { masyarakat. }\end{array}$ & $\begin{array}{l}12.1 \\
12.2 \\
12.3\end{array}$ & $\begin{array}{l}\text { Berperilaku jujur, tegas, dan manusiawi. } \\
\text { Berperilaku yang mencerminkan ketakwaan, dan } \\
\text { akhlak mulia. } \\
\text { Berperilaku yang dapat diteladani oleh peserta } \\
\text { didik dan anggota masyarakat di sekitarnya. }\end{array}$ \\
\hline 13. & $\begin{array}{l}\text { Menampilkan diri sebagai pribadi } \\
\text { yang mantap, stabil, dewasa, arif, } \\
\text { dan berwibawa. }\end{array}$ & $\begin{array}{l}13.1 \\
13.2\end{array}$ & $\begin{array}{l}\text { Menampilkan diri sebagai pribadi yang mantap } \\
\text { dan stabil. } \\
\text { Menampilkan diri sebagai pribadi yang dewasa, } \\
\text { arif, dan berwibawa. }\end{array}$ \\
\hline 14. & $\begin{array}{l}\text { Menunjukkan etos kerja, } \\
\text { tanggung jawab yang tinggi, rasa } \\
\text { bangga menjadi guru, dan rasa } \\
\text { percaya diri. }\end{array}$ & $\begin{array}{l}14.1 \\
14.2\end{array}$ & $\begin{array}{l}\text { Menunjukkan etos kerja dan tanggung jawab } \\
\text { yang tinggi. } \\
\text { Bangga menjadi guru dan percaya pada diri } \\
\text { sendiri. } \\
\text { Bekerja mandiri secara profesional. } \\
\end{array}$ \\
\hline 15 & $\begin{array}{l}\text { Menjunjung tinggi kode etik } \\
\text { profesi guru. }\end{array}$ & $\begin{array}{l}15.1 \\
15.2 \\
15.3 \\
\end{array}$ & $\begin{array}{l}\text { Memahami kode etik profesi guru. } \\
\text { Menerapkan kode etik profesi guru. } \\
\text { Berperilaku sesuai dengan kode etik guru. }\end{array}$ \\
\hline \multicolumn{4}{|c|}{ Kompetensi Sosial } \\
\hline 16. & $\begin{array}{l}\text { Bersikap inklusif, bertindak } \\
\text { objektif, serta tidak diskriminatif } \\
\text { karena pertimbangan jenis } \\
\text { kelamin, agama, ras, kondisi fisik, } \\
\text { latar belakang keluarga, dan status } \\
\text { sosial ekonomi. }\end{array}$ & 16.1 & $\begin{array}{l}\text { Bersikap inklusif dan objektif terhadap peserta } \\
\text { didik, teman sejawat dan lingkungan sekitar } \\
\text { dalam melaksanakan pembelajaran. } \\
\text { Tidak bersikap diskriminatif terhadap peserta } \\
\text { didik, teman sejawat, orang tua peserta didik dan } \\
\text { lingkungan sekolah karena perbedaan agama, } \\
\text { suku, jenis kelamin, latar belakang keluarga, dan } \\
\text { status sosial-ekonomi. }\end{array}$ \\
\hline 17. & $\begin{array}{l}\text { Berkomunikasi secara efektif, } \\
\text { empati, dan santun dengan sesama } \\
\text { pendidik, tenaga kependidikan, } \\
\text { orang tua, dan masyarakat. }\end{array}$ & $\begin{array}{l}17.1 \\
17.2 \\
17.3\end{array}$ & $\begin{array}{l}\text { Berkomunikasi dengan teman sejawat dan } \\
\text { komunitas ilmiah lainnya secara santun, empati } \\
\text { dan efektif. } \\
\text { Berkomunikasi dengan orang tua peserta didik } \\
\text { dan masyarakat secara santun, empati, dan efektif } \\
\text { tentang program pembelajaran dan kemajuan } \\
\text { peserta didik. } \\
\text { Mengikutsertakan orang tua peserta didik dan } \\
\text { masyarakat dalam program pembelajaran dan } \\
\text { dalam mengatasi kesulitan belajar peserta didik. }\end{array}$ \\
\hline 18. & $\begin{array}{l}\text { Beradaptasi di tempat bertugas di } \\
\text { seluruh wilayah Republik } \\
\text { Indonesia yang memiliki } \\
\text { keragaman sosial budaya. }\end{array}$ & 18.2 & $\begin{array}{l}\text { Beradaptasi dengan lingkungan tempat bekerja } \\
\text { dalam rangka meningkatkan efektivitas sebagai } \\
\text { pendidik, termasuk memahami bahasa daerah } \\
\text { setempat. } \\
\text { Melaksanakan berbagai program dalam } \\
\text { lingkungan kerja untuk mengembangkan dan } \\
\text { meningkatkan kualitas pendidikan di daerah yang } \\
\text { bersangkutan. }\end{array}$ \\
\hline 19. & $\begin{array}{l}\text { Berkomunikasi dengan komunitas } \\
\text { profesi sendiri dan profesi lain } \\
\text { secara lisan dan tulisan atau } \\
\text { bentuk lain. }\end{array}$ & 19.1 & $\begin{array}{l}\text { Berkomunikasi dengan teman sejawat, profesi } \\
\text { ilmiah, dan komunitas ilmiah lainnya melalui } \\
\text { berbagai media dalam rangka meningkatkan } \\
\text { kualitas pendidikan. }\end{array}$ \\
\hline
\end{tabular}




\begin{tabular}{|c|c|c|c|}
\hline & & 19.2 & $\begin{array}{l}\text { Mengomunikasikan hasil-hasil inovasi } \\
\text { pembelajaran kepada komunitas profesi sendiri } \\
\text { secara lisan dan tulisan atau bentuk lain. }\end{array}$ \\
\hline \multicolumn{4}{|c|}{ Kompetensi Profesional } \\
\hline 20. & $\begin{array}{l}\text { Menguasai materi, struktur, } \\
\text { konsep, dan pola pikir keilmuan } \\
\text { yang mendukung mata pelajaran } \\
\text { yang diampu. }\end{array}$ & 20.1 & $\begin{array}{l}\text { Menguasai konsep dasar matematika, sains, } \\
\text { bahasa, pengetahuan sosial, agama, seni, } \\
\text { pendidikan jasmani, kesehatan dan gizi sebagai } \\
\text { sarana pengembangan untuk setiap bidang } \\
\text { pengembangan anak TK/PAUD. } \\
\text { Menguasai penggunaan berbagai alat permainan } \\
\text { untuk mengembangkan aspek fisik, kognitif, } \\
\text { sosial-emosional, nilai moral, sosial budaya, dan } \\
\text { bahasa anak TK/PAUD. } \\
\text { Menguasai berbagai permainan anak. }\end{array}$ \\
\hline 21. & $\begin{array}{l}\text { Menguasai standar kompetensi } \\
\text { dan kompetensi dasar mata } \\
\text { pelajaran/bidang pengembangan } \\
\text { yang diampu. }\end{array}$ & $\begin{array}{l}21.1 \\
21.2 \\
21.3\end{array}$ & $\begin{array}{l}\text { Memahami kemampuan anak TK/PAUD dalam } \\
\text { setiap bidang pengembangan. } \\
\text { Memahami kemajuan anak dalam setiap bidang } \\
\text { pengembangan di TK/PAUD. } \\
\text { Memahami tujuan setiap kegiatan } \\
\text { pengembangan. }\end{array}$ \\
\hline 22. & $\begin{array}{l}\text { Mengembangkan materi } \\
\text { pembelajaran yang diampu secara } \\
\text { kreatif. }\end{array}$ & $\begin{array}{l}22.1 \\
22.2\end{array}$ & $\begin{array}{l}\text { Memilih materi bidang pengembangan yang } \\
\text { sesuai dengan tingkat perkembangan peserta } \\
\text { didik. } \\
\text { Mengolah materi bidang pengembangan secara } \\
\text { kreatif sesuai dengan tingkat perkembangan } \\
\text { peserta didik. }\end{array}$ \\
\hline 23. & $\begin{array}{l}\text { Mengembangkan keprofesionalan } \\
\text { secara berkelanjutan dengan } \\
\text { melakukan tindakan reflektif. }\end{array}$ & $\begin{array}{l}23.1 \\
23.2 \\
23.3 \\
23.4\end{array}$ & $\begin{array}{l}\text { Melakukan refleksi terhadap kinerja sendiri } \\
\text { secara terus menerus. } \\
\text { Memanfaatkan hasil refleksi dalam rangka } \\
\text { peningkatan keprofesionalan. } \\
\text { Melakukan penelitian tindakan kelas untuk } \\
\text { peningkatan keprofesionalan. } \\
\text { Mengikuti kemajuan zaman dengan belajar dari } \\
\text { berbagai sumber. }\end{array}$ \\
\hline 24. & $\begin{array}{l}\text { Memanfaatkan teknologi } \\
\text { informasi dan komunikasi untuk } \\
\text { berkomunikasi dan } \\
\text { mengembangkan diri. }\end{array}$ & & $\begin{array}{l}\text { Memanfaatkan teknologi informasi dan } \\
\text { komunikasi dalam berkomunikasi. } \\
\text { Memanfaatkan teknologi informasi dan } \\
\text { komunikasi untuk pengembangan diri. }\end{array}$ \\
\hline
\end{tabular}

Kompetensi-kompetensi ini harus dibuktikan dengan sertifikat pendidik. Jadi kompetensi ini dibangun bukan hanya melalui Strata 1(S1) atau Diploma IV (D IV), tetapi juga melalui pendidikan profesi yang nantinya memperoleh sertifikat sebagai pendidik. Berdasarkan Peraturan Pemerintah Nomor 16 tahun 2007, untuk memperoleh sertifikat profesional sebagai guru, guru harus menunjukkan kemampuan "melakukan refleksi untuk memperbaiki kualitas pembelajaran" menggunakan hasil refleksi untuk memperbaiki kualitas pembelajaran dalam mata pelajaran mereka dan "mengembangkan profesionalisme mereka." 


\section{Implikasi Kebijakan Kompetensi Pedagogi Guru PAUD \\ 1. Mewujudkan Guru PAUD yang Kompeten}

Adanya UU tentang guru dan dosen tersebut tentunya dalam upaya memperbaiki persoalan-persoalan di atas sehingga dari guru yang memiliki kompetensi dan profesional diharapkan muncul anak didik yang memiliki kemampuan sesuai tujuan pendidikan nasional. Undang-Undang Nomor 14 Tahun 2005 tentang Guru dan Dosen merupakan sebuah perjuangan sekaligus komitmen untuk meningkatkan kualitas kompetensi guru seiring dengan peningkatan kesejahteraan.

Mengajar adalah menggugah dan membantu terjadinya gejala belajar di kalangan siswa (Raka Joni 1993) dan Bowden dan Ference (1998) mengatakan bahwa mengajar bukan berarti mentransfer pengetahuan kepada siswa, tetapi membantu siswa mengembangkan pengetahuan mereka. Galileo menegaskan bahwa sebenarnya kita tidak dapat mengajarkan apapun, kita hanya dapat membantu peserta didik untuk menemukan dirinya dan mengaktualisasikan dirinya. Padahal setiap pribadi manusia memiliki "self-hidden potential excellence" (mutiara talenta yang tersembunyi di dalam diri), sementara tugas pendidik yang membantu peserta didik untuk menemukan dan mengembangkannya seoptimal mungkin talenta itu masih kurang berhasil .

Kata mengajar mempunyai arti memberikan pengetahuan yang mereka miliki terlebih dahulu kepada muridnya sehingga mereka bisa mengerti. Kata mendidik mempunyai makna yang lebih dalam karena selain guru mempunyai tugas untuk mengajar, tetapi mereka juga memiliki tanggung jawab untuk mengarahkan anak muridnya menjadi seorang manusia yang berbudi luhur. Guru yang profesional pada dasarnya ditentukan oleh attitude-nya yang berarti pada tataran kematangan yang mempersyaratkan willingness dan ability, baik secara intelektual maupun pada kondisi yang prima.

Jaques Delors (1996) mengatakan bahwa untuk meningkatkan kualitas pendidikan sangat tergantung pada peningkatan rekrutmen, pelatihan, status sosial, dan kondisi kerja guru. Guru membutuhkan memiliki pengetahuan dan keterampilan yang tepat, memiliki karakter pribadi, memiliki prospek profesional, dan motivasi. Upaya yang harus dilakukan adalah sebagai berikut.

a. Perlu upaya peningkatan penghasilan guru agar dapat meningkatkan kualifikasi dirinya yaitu dengan menyetarakan pembayaran gaji guru diseimbangkan dengan beban. Program apapun yang akan diterapkan pemerintah tetapi jika gaji guru rendah tidak akan berhasil. Jelaslah untuk memenuhi kebutuhan hidupnya guru akan mencari pekerjaan tambahan untuk mencukupi kebutuhannya. Peningkatan tersebut harus memenuhi kebutuhan untuk: Pembiayaan pembinaan guru dalam jabatan, pelaksanaan guru sebagai pendidik profesional dan sandang pangan perumahan, transpor, kesehatan, buku, melakukan riset dan tabungan masa depan.

b. Untuk memenuhi jumlah pengadaan guru, program pendidikan pengadaan guru tersebut seharusnya lebih ditujukan untuk memilih dan memilah calon peserta didik yang berkualitas daripada berfungsi sebagai pengembangan peserta didik, sehingga kualitas lulusannya benar benar meyakinkan seperti 
guru lulusan sebelum Indonesia Merdeka. Program pendidikan PAUD tersebut perlu:

1) Memilih calon mahasiswa yang memiliki kepandaian yang memadai dan bagi kelas karyawan telah mengikuti pendidikan guru profesional. Untuk calon pengajar adalah minimal S1, atau pengajar guru profesional adalah S 2 dengan IPK minimal 3,3 dan piawai dalam mengelola proses pendidikan.

2) Menerapkan model pembelajaran: learning to know, learning to do, leaning to live together, how to be, yang menjadikan ilmu sebagai way of knowing untuk menyesuaikan dengan perkembangan penggunaan model pembelajaran. Pembelajaran yang menumbuhkan kreativitas guru di lapangan yang menjadi "ujung tombak" dalam penyelenggaraan pendidikan.

3) Memiliki sarana dan prasarana yang lengkap dengan dana yang memadai

4) Melakukan sistem evaluasi yang menilai siswa dalam : kemampuan menerapkan metode inkuiri dalam learning to how, kemampuan menerapkan prinsip atau hukum untuk memecahkan masalah learning to do, kemampuan learning to live together dan learning to be. sedang kan evaluasi tahap kedua aspek yang dinilai adalah: kemauan merencanakan dan mengembangkan program, kemampuan mengelola proses pembelajaran, mengembangkan evaluasi, menganalisa kekuatan dan kelemahan program, dan menyempurnakan program

5) Hasil c etak kepribadian manusia adalah hasil dari proses transformasi pengetahuan dan pendidikan yang dilakukan secara humanis.

\section{Kemampuan Pedagogi yang perlu dimiliki Guru PAUD dalam Pembelajaran AUD}

Guru yang baik harusnya dapat menghantarkan anak didiknya ke arah kehidupan dan masa depan yang lebih baik karena masa depan orang dewasa saat ini sangat ditentukan cara guru mengajar saat ini seperti sebuah sajak yang dikemukakan oleh Delors 'The child is father of the Man'.

Menurut Delors pendidikan seharusnya dirancang berdasarkan empat dasar cara belajar sepanjang hidup seseorang, yang dikenal dengan pilar pendidikan di antaranya dijelaskan sebagai berikut.

Belajar untuk tahu ( learning to know), dalam proses pembelajaran setiap anak didorong untuk memahami lingkungannya agar dapat hidup bermartabat, mengembangkan keterampilan untuk bekerja sesuai dengan bidangnya dan untuk berkomunikasi. Pada akhirnya pengetahuan itu dipahami dengan cara yang menyenangkan dan melalui penemuan. Walaupun pengetahuan terus berubah dan berkembang tetapi bila telah tertanam cara berpikir ilmiah, maka segala permasalahan yang dihadapi anak kelak akan menjadi tantangan yang selalu ingin dipecahkan secara ilmiah pula.

Belajar mengetahui mengisyaratkan belajar untuk belajar, berarti belajar mengerahkan segala daya untuk berkonsentrasi, mengingat, dan berpikir. Anak harus diajak untuk berkonsentrasi pada benda atau orang misalnya melalui permainan dan melakukan kerja ilmiah (Delors, 1996;88). 
Dalam proses belajar, pembelajaran dapat dibelajarkan oleh guru melalui metode baik induktif maupun deduktif. Tetapi untuk tingkatan PAUD sebaiknya secara induktif melalui keterampilan ilmiah, mulai dari yang bersifat konkret ke yang abstrak dan dari dekat ke yang jauh, dari yang sederhana menuju ke yang kompleks. Melalui metode deduktif anak akan tahu bagaimana suatu pengetahuan diperoleh.

Di ruang kelas umumnya guru dalam membelajarkan siswanya tidak dilandasi oleh pilar pendidikan maupun teori pembelajaran. Pembelajaran disampaikan kebanyakan melalui metode ceramah sehingga seperti pepatah Cina "I hear I forget", sehingga segala sesuatu yang dikatakan oleh guru akan segera dilupakan oleh siswa seharusnya pepatah yang berbunyi "I do I understand" itulah yang dilakukan di ruang kelas.

Guru juga jarang menggunakan media pembelajaran dengan alasan jumlahnya kurang, sudah rusak atau terlalu merepotkan. Alat peraga tidak digunakan karena oleh kepala sekolah tidak boleh dipakai takut rusak atau guru tidak terampil menggunakan alat-alat yang ada. Padahal anak-anak sedang dalam masa operasional konkret, artinya, pengetahuan dapat dipahami oleh anak-anak bila didahului dengan mengoperasikan benda-benda konkrit terlebih dahulu (Piaget) atau hands-on activities - minds-on activities artinya intelektualnya akan bekerja bila didahului dengan menghidupkan keterampilan manualnya yang didukung oleh Dewey bahwa anak baru akan paham bila dalam belajar melakukan sesuatu (learning by doing).

Sebenarnya bila alat-alat yang diperlukan tidak tersedia di sekolah bisa diganti bila guru pengajarnya kreatif. Misalnya pengetahuan untuk sains atau pengembangan kognitif bisa menggunakan benda-benda yang ada di ruang kelas, lingkungan sekitar, atau membawa dari rumah. Sebab semua alat tersebut mungkin sudah dilihat anak, hanya mungkin masih salah secara konseptual. Di sinilah peranan konstruksi pengetahuan yang harus dilakukan oleh anak dan difasilitasi oleh guru.

Kesulitan yang dialami anak dalam memahami pengetahuan baru pada bidang studi yang sudah dibelajarkan oleh guru, karena dalam proses belajar siswa tidak aktif dalam mengonstruk pengetahuannya. Akibatnya pengetahuan itu, hanya sekedar dipakai untuk mengisi tes tertulis yang sifatnya hafalan sesuai dengan persoalan yang dirancang oleh guru tanpa mengetahui tujuan pembelajaran.

Belajar untuk melakukan (Learning to do) artinya pengetahuan yang telah diperoleh anak seharusnya digunakan dalam kehidupan sehari-hari. Belajar untuk melakukan penting dilatihkan pada anak agar pada masa mendatang di mana perekonomian yang berasal dari keuntungan industri bergantung pada kemampuan mentransformasikan kemajuan pengetahuan dalam melakukan inovasi yang dapat menghasilkan usaha dan pekerjaan yang baru. Anak-anak yang dibelajarkan melakukan akan tahu yang harus dilakukan untuk mengurangi ketergantungannya pada orang lain, karena penuh dengan inovasi.

Dalam ruang kelas, belajar melakukan tidak dibelajarkan pada siswa, andai pun dibelajarkan tidak secara berkesinambungan. Hal ini tampak pada soalsoal yang dirancang oleh guru, jarang atau tidak pernah yang menggunakan 
keterampilan berpikir kreatif siswa. Hasil belajar siswa hanya diukur berdasarkan pengetahuannya saja.

Sebenarnya belajar melakukan dapat dikembangkan di ruang kelas melalui kerja kelompok, karena bisa saja inovasi ditemukan saat anak-anak melakukan percobaan secara berkelompok.

Bila belajar melakukan tidak dibelajarkan di ruang kelas, akibatnya di masa depan akan jarang diperjualkan sesuatu yang berupa hasil inovasi sehingga barang yang dijual atau makanan yang dijual di pasaran segera ditinggalkan oleh konsumennya karena membosankan. Akibat jangka panjang adalah akan timbul pengangguran dan kemiskinan. Orang yang memiliki inovasi yang baik akan melihat masalah sebagai tantangan. Contohnya, singkong yang kurang enak, di tangan seorang inovator akan menjadi makanan yang bergengsi, demikian juga dengan berbagai bentuk taman hiburan, orang cepat merasa bosan, sehingga dibutuhkan inovator.

Belajar hidup bersama, belajar hidup dengan orang lain (learning to live together, learning to live with others), mungkin akan menjadi isu besar dalam dunia pendidikan. Konflik terjadi di berbagai belahan dunia maupun di Indonesia karena perbedaan ideologi, golongan, suku, ras, agama dan keyakinan. Betapa murahnya harga nyawa manusia, sehingga hal-hal yang kecil menjadi besar dan memusnahkan fasilitas negara, perusahaan, perumahan dan rumah ibadah. Tugas pendidik adalah mengajarkan keberagaman ras manusia, agama, suku, golongan dan kesadaran akan persamaan dan saling ketergantungan di antara semua manusia. Semua itu dibelajarkan sejak usia dini tentang keberagaman dan persamaan. Kesadaran itu seharusnya dimodelkan oleh guru, melalui penerimaan perbedaan di antara siswa. Kesadaran itu juga bisa dijadikan tema dalam membelajarkan siswa untuk menghargai orang lain dan keuntungan dalam perbedaan.

Di ruang kelas membelajarkan siswa dalam kebersamaan bisa dilakukan melalui kerja kelompok atau tim. Dalam bekerja kelompok atau kerja sama untuk meraih penghargaan anak-anak harus dapat keluar dari kebiasaan rutin, keluar dari perbedaan bahkan keluar dari konflik individual. Di TK daerah pedesaan yang umumnya siswanya homogen, melatih dalam kebersamaan dapat dilakukan di antara siswa dengan kemampuan intelektual dan latar belakang ekonomi yang heterogen. Umumnya siswa yang memiliki intelektual yang lebih tinggi tidak mau bekerja sama dengan siswa yang intelektualnya rendah karena merasa tidak diuntungkan. Keadaan ini sering membuat anak-anak yang intelektualnya rendah menjadi rendah diri sehingga terjadi jurang di antara siswa dalam satu ruang kelas.

Guru kebanyakan tidak menggunakan pendekatan belajar yang dapat membangkitkan kebersamaan seperti pendekatan cooperative learning dalam membelajarkan siswanya dengan metode storytelling. Kebersamaan ini juga dapat dilatihkan pada anak-anak melalui permainan yang berkelompok seperti bebentengan dan go back to the door. Di sini anak dilatih untuk menjalin kerja sama agar kelompoknya dapat menjadi the great team. Melalui kerja kelompok anak-anak dapat belajar menghargai dan saling menghormati dalam perbedaan. 
Belajar menjadi diri sendiri (learning to be). Pendidikan seharusnya dapat menciptakan manusia yang seutuhnya jiwa dan raga, cerdas, sensitif, memiliki perasaan akan estetika, tanggung jawab terhadap diri sendiri dan manusia yang mempunyai nilai-nilai spiritual. Setiap manusia harus dapat berkembang secara bebas, berpikir kritis dan melakukan yang diyakininya dalam kehidupan yang berbeda-beda. Pendidikan seharusnya dapat membuat orang bebas berpikir, merasa diperlakukan adil, bebas bekerja dan berimajinasi untuk mengembangkan bakat dan dapat mengendalikan diri.

Keempat pilar pendidikan di atas dapat diwujudkan bila kuantitas dan kualitas guru menunjang kegiatan belajar mengajar yang baik. Melalui pembelajaran yang bermutu diharapkan dunia tempat manusia hidup menjadi suatu tempat yang lebih baik untuk ditinggali, di mana orang belajar menghargai hak, yang bisa menunjukkan saling memahami, dan menggunakan manfaat pengetahuan agar lebih memajukan perkembangan manusia daripada mengedepankan perbedaan-perbedaan di antara manusia belaka.

\section{E. Penerapan 4 Pilar Pendidikan dalam Pembelajaran di PAUD}

\section{Tema: KUCING}

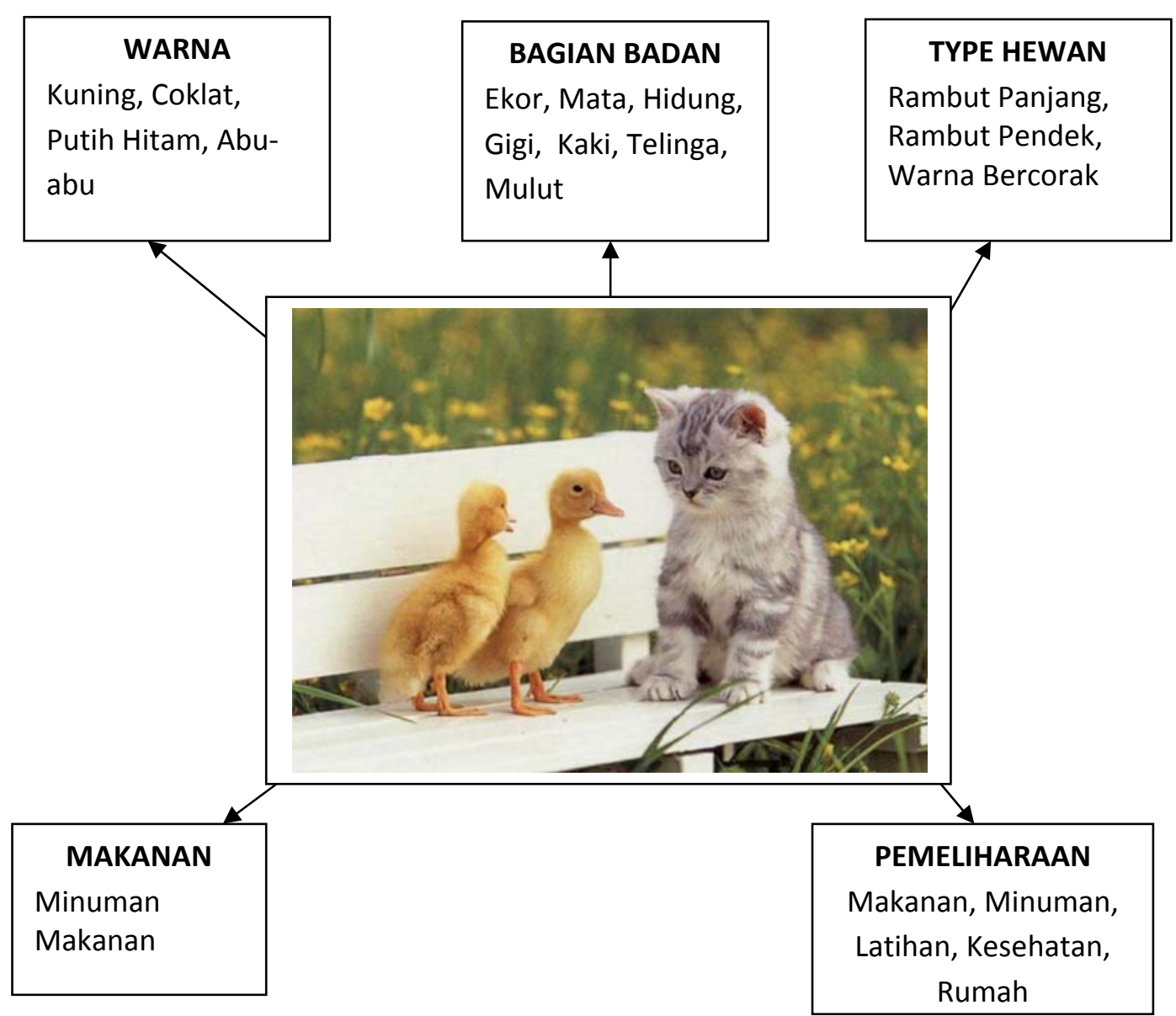


Contoh Pemetaan Indikator Yang Dikembangkan

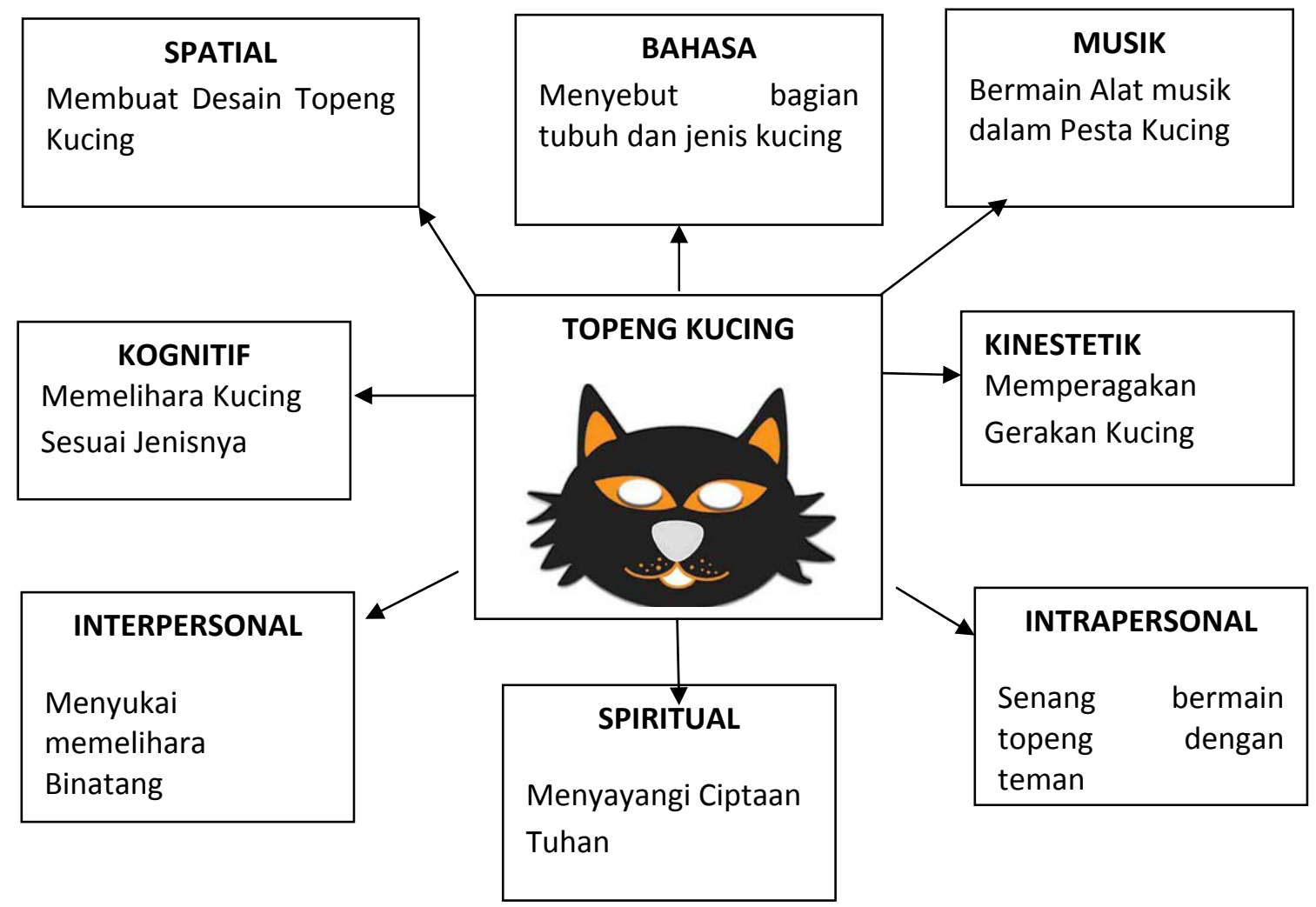

Contoh: Satuan Kegiatan Harian (SKH/RPP)

Kelompok : B

Semester/Minggu : II/VIII

Tema/Sub Tema : Binatang

\begin{tabular}{|c|l|l|l|}
\hline \multicolumn{1}{|c|}{ INDIKATOR } & \multicolumn{1}{|c|}{$\begin{array}{c}\text { KEGIATAN } \\
\text { PEMBELAJARAN }\end{array}$} & $\begin{array}{c}\text { ALAT DAN } \\
\text { SUMBER }\end{array}$ & EVALUASI \\
\hline & $\begin{array}{l}\text { I. PENDAHULUAN } \\
\text { Salam,Berbaris, Senam } \\
\text { Ritmik }\end{array}$ & & \\
\hline $\begin{array}{l}\text { Berdoa sebelum dan } \\
\text { sesudah kegiatan (A) }\end{array}$ & Hafalan doa mau makan & & \\
\hline & Olah Raga Bersama & $\begin{array}{l}\text { Kertas, gunting, } \\
\text { lem, tali, manik } \\
\text { manik, pinsil } \\
\text { warna, topeng } \\
\text { kucing }\end{array}$ & \\
& \multicolumn{1}{|l|}{$\begin{array}{l}\text { II. KEGIATAN INTI } \\
\text { Pesta Topeng Kucing }\end{array}$} & & \\
& & &
\end{tabular}




\begin{tabular}{|c|c|c|c|}
\hline $\begin{array}{l}\text { SPRITUAL } \\
\text { Mengenal Ciptaan } \\
\text { Allah }\end{array}$ & $\begin{array}{l}\text { Sifat Allah Al Rohman dan } \\
\text { Al Rohim }\end{array}$ & & \\
\hline $\begin{array}{l}\text { Logika } \\
\text { Mengetahui satu } \\
\text { hubungan }\end{array}$ & $\begin{array}{l}\text { Menjelaskan memelihara } \\
\text { kucing sesuai jenisnya }\end{array}$ & & Proses \\
\hline $\begin{array}{l}\text { Musikal } \\
\text { Bernyanyi satu lagu }\end{array}$ & Menyanyi “Kucing” & & Performens \\
\hline $\begin{array}{l}\text { Linguistik } \\
\text { Menceritakan } \\
\text { sesuatu yang telah } \\
\text { dilihat }\end{array}$ & $\begin{array}{l}\text { Menceritakan bagian tubuh } \\
\text { dan jenis kucing }\end{array}$ & & Proses \\
\hline $\begin{array}{l}\text { Spatial } \\
\text { Menggunting benda } \\
\text { tiga dimensi dengan } \\
\text { berbagai media }\end{array}$ & $\begin{array}{l}\text { Membuat desain dengan } \\
\text { menggunting dan menempel } \\
\text { topeng kucing }\end{array}$ & & Hasil karya \\
\hline $\begin{array}{l}\text { Kinestetik } \\
\text { Melempar, } \\
\text { meloncat, berjinjit }\end{array}$ & Meniru gerakan kucing & & Performens \\
\hline $\begin{array}{l}\text { Intrapersonal } \\
\text { Senang bermain } \\
\text { dengan teman }\end{array}$ & $\begin{array}{l}\text { Bermain topeng kucing } \\
\text { dengan teman }\end{array}$ & & Performens \\
\hline \multirow{2}{*}{$\begin{array}{l}\text { Interpersonal } \\
\text { Menyayangi sesama } \\
\text { makhluk }\end{array}$} & $\begin{array}{l}\text { Menyukai memelihara hewan } \\
\text { peliharaan }\end{array}$ & & Observasi \\
\hline & III. ISTIRAHAT & & \\
\hline \multirow{3}{*}{$\begin{array}{l}\text { Senang bermain } \\
\text { dengan teman }\end{array}$} & Bermain bersama & Alat bermain & \\
\hline & $\begin{array}{l}\text { Cuci tangan, berdoa makan } \\
\text { bersama }\end{array}$ & $\begin{array}{lr}\text { Lap, } & \text { air, } \\
\text { mangkuk } & \text { cuci } \\
\text { tangan }\end{array}$ & \\
\hline & IV. PENUTUP & & \\
\hline \multirow[t]{3}{*}{$\begin{array}{l}\text { Dapat memegang } \\
\text { pensil dengan benar }\end{array}$} & Menulis 'Kucing” & $\begin{array}{l}\text { Pensil, buku } \\
\text { kegiatan }\end{array}$ & \\
\hline & Evaluasi & & \\
\hline & Doa, Salam & & \\
\hline
\end{tabular}

\section{F. Kesimpulan}

1. Pendidikan usia dini merupakan usaha mengupayakan dan mengembangkan seluruh potensi kemampuan anak sejak lahir sampai berusia 6 tahun yang pada akhirnya merupakan fondasi awal untuk mengembangkan bangsa, maka dari itu dibutuhkan tenaga pendidik yang mampu mengembangkan seluruh potensi anak usia dini tersebut

2. Karena perannya yang sangat penting, guru dituntut memiliki profesionalisme yang tinggi dalam melaksanakan tugasnya dan kesediaannya untuk berubah ke arah yang lebih baik. 
3. Tenaga pendidik PAUD yang profesional adalah yang miliki kompetensi dan kualifikasi sesuai UU No 14 tahun 2005 dan PP No 16 tahun 2007, meskipun kenyataan di lapangan masih banyak guru PAUD yang belum memenuhi kualifikasi tersebut, khususnya lemahnya kopetensi kepribadian dan kualifikasi akademik

4. Implikasi tuntutan Undang Undang No 14 tahun 2005, maka perlu diaplikasikan pilar pendidikan d yang telah dicanangkan oleh UNESCO di PAUD sesuai dengan pernyataan Delors

\section{DAFTAR PUSTAKA}

Delors, J. (1996). Learning The Treasure Within. UNESCO Publishing. The Australia National Commision for UNESCO

Erman Syamsuddin (2011) Kebijakan Dan Program PAUD Tahun 2011. Direktorat Jenderal Pendidikan Anak Usia Dini, Nonformal, dan informal Kementerian Pendidikan Nasional

Herr, Judy, Larson Ivone (200) Creative Resources For The Early Childhood Classroom. (Third Edition).

Ornstein, Allan C. and Levine, Daniel U. (1984). An Introduction to the Foundation of Education (Third edition). Boston: Houghton Mifflin Company.

Raka Joni, T. (1992). Pokok-pokok Pikiran Mengenai Pendidikan Guru. Jakarta: Konsorsium Ilmu Pendidikan, Direktorat Jenderal Pendidikan Tinggi, Departemen Pendidikan dan Kebudayaan

PP Menteri Pendidikan Nasional RI No 16 Tahun 2007 tentang standar kualifikasi akademik dan kompetensi guru

PP RI No.19 Tahun 2005 Tentang Standar Nasional Pendidikan

Undang-Undang Republik Indonesia No. 20 Tahun 2003 tentang Sistem Pendidikan Nasional. Jakarta: BP. Cipta Jaya.

Undang-undang Republik Indonesia nomor 14 tahun 2005 tentang Guru dan Dosen

UNICEF. (2002). A World Fit for Children, New York.

http://www.slideshare.net/penggawa/pendidikan-karakter-5758744

http://beta.pikiran-rakyat.com/index.php?mib=beritadetail\&id=9232

\section{BIODATA PENULIS}

Margaretha Sri Yuliariatiningsih adalah dosen UPI Kampus Cibiru.

Taty Setiaty adalah dosen Fakultas Keguruan dan Ilmu Pendidikan, Universitas Pasundan Bandung 